This is a pre-print of an article published in Sustainability science (Ed. Springer). The final authenticated version is available online at: DOI 10.1007/s11625-018-0558-1

\title{
More dams, more violence? \\ A global analysis on resistances and repression around conflictive dams through co-produced knowledge
}

\author{
Daniela Del Bene ${ }^{* 1}$, Arnim Scheidel ${ }^{1}$, Leah Temper ${ }^{1,2}$ \\ ${ }^{1}$ Institute of Environmental Science and Technology (ICTA), Universitat \\ Autónoma de Barcelona (UAB), Barcelona, Spain. \\ 2 McGill University, Canada \\ * Corresponding author. Email: d.delbene@gmail.com
}

\begin{abstract}
The present article analyses a unique database of 220 dam related environmental conflicts, retrieved from the Global Atlas on Environmental Justice (EJAtlas), and based on knowledge co-production between academics and activists. Despite well-known controversial social and environmental impacts of dams, efforts to increase renewable energy generation have reinstated the interest into hydropower development globally. People affected by dams have largely denounced such 'unsustainabilities' through collective non-violent actions. Nevertheless, we found that repression, criminalization, violent targeting of activists and assassinations are recurrent features of conflictive dams. Violent repression is particularly high when indigenous people are involved. Indirect forms of violence are also analyzed through socio-economic, environmental, and health impacts. We argue that increasing repression of the opposition against unwanted energy infrastructures does not only serve to curb specific protest actions, but also aims to delegitimize and undermine differing understanding of sustainability, epistemologies, and world-views. This analysis cautions that allegedly sustainable renewables such as hydropower often replicates patterns of violence within a frame of an 'extractivism of renewables'. We finally suggest that co-production of knowledge between scientists, activists, and communities should be largely encouraged in order to investigate sensitive and contentious topics in sustainability studies.
\end{abstract}

\section{Keywords}

Hydroelectric dams; violence; extractivism; ecological distribution conflicts; renewable energies; co-production of knowledge 


\section{Introduction}

"With the right commitments, better hydro will play an even greater role in delivering modern energy and water services in a climate-constrained world" (Richard Taylor, CEO of International Hydropower Association (IHA), 2017) ${ }^{1}$

"Large hydro is a very big part of the solution for Africa and South Asia and Southeast Asia. I fundamentally believe we have to be involved," [The earlier move out of hydro]

"was the wrong message.

That was then. This is now. We are back."

(Rachel Kyte, World Bank, 2013)

As affirmed above by the World Bank's vice president for sustainable development, the world economy's largest donor is now full swing back into large-scale hydro. Following a phase of greater caution towards hydropower from the early ' 90 s due to its disruptive social and environmental impacts (Goldsmith and Hildyard, 1984), this move back to hydro is seen as a way to simultaneously reconcile the dual goals of carbon reduction and economic development.

The World Bank (WB) is not alone in this new wave of dam financing. New actors like pension- and insurance funds, the New Development Bank, and increasingly Chinese capital are today leading the global hydropower sector in terms of number and size of dams built, investment amounts, and geographical coverage (McDonald et al., 2009; Bosshard, 2009; International Rivers, 2012). Moreover, also climate funding, including the Clean Development Mechanism (CDM), and the Green Climate Fund (GCF, currently being negotiated), is especially interested in plants deemed to have less environmental impacts for their design and technology, like the Run-of-Rivers (RoR) schemes ${ }^{3}$. Hydroelectricity seems to turn again into a new point of consensus for low-carbon sustainable energy generation, the politics of development, green growth, and climate mitigation (Cole et al, 2014; Ahlers et al. 2015).

In 2017, the International Hydropower Association opened its congress with the slogan "We Can Deliver Better Hydro". According to its CEO Richard Taylor, the hydro sector can improve and have a greater role to address climate and environmental concerns through improved governance, management, and technology.

However, the claim that hydropower can now address sustainability concerns is not reflected in the critical findings from the sustainability sciences. Renewable energy does not necessarily mean sustainable energy. A large body of scientific literature has documented the severe environmental and social impacts of dams (Fearnside 2016, 2004, 1999; Grumbine and Pandit, 2013; Sovacool and Bulan, 2013; WCD, 2000) as well as highlighted the limitations of dam impact assessments (Brismar, 2004; Erlewein, 2013; Fearnside, 2016). Moreover, all large-scale renewables require commonly large infrastructures or large amounts of land area (Scheidel and Sorman, 2012). As dams

\footnotetext{
${ }^{1}$ Statement at the World Hydropower Congress in Addis Ababa, 2017 https://www.hydropower.org/news/date/201606

"'World Bank turns to hydropower to square development with climate change"; available at "https://www.washingtonpost.com/business/economy/world-bank-turns-to-hydropower-to-squaredevelopment-with-climate-change/2013/05/08/b9d60332-b1bd-11e2-9a98-4be1688d7d84_story.html ${ }^{3}$ https://cdm.unfccc.int/
} 
generally provide energy to industries and cities, and often support specific sectors with water and electricity, such as mining or agro-industries, they constitute a key element in the geographies of extractivism ${ }^{4}$, capital accumulation, and growth-oriented economies (Yacoub et al. 2015).

Both large and smaller dams provoke social and environmental conflicts. Such conflicts are increasing as communities and groups organize in greater numbers to oppose undemocratic hydro infrastructure and the extractivist operations their energy feeds such as refineries, other industries, etc. (Martinez-Alier et al., 2010, Schlosberg, 2004; McCully 2001). Opposition to dams arises not only to denounce the social and ecological impacts and distress people suffer, but also to question the narrow techno-economic rationality that has shaped development policy and sustainability politics for decades (Goldman, 2001). In doing so, grassroots activists have contributed to pathways towards more sustainable energy provision by shedding light on the concerns and impacts of unsustainable resource uses (Scheidel et al, this feature) while actively aiming to transform them towards more sustainable outcomes (Temper et al., this feature).

At the same time, communities opposing dams increasingly face strong repression and violence. An emblematic example is the resistance against the Agua Zarca hydro plant, for which well-known activist Berta Caceres was killed in 2016 (EJAtlas 2016a). The UN Commission on Human Rights has weighed in recently on the critical situation of Environmental Human Rights Defenders (EHRDs) (OHCHR 2016, 2017), while UN special rapporteur on the rights of Indigenous Peoples, Victoria Tauli-Corpuz, stated in March 2016 that "the pattern of killings in many countries (of EHRDs) is becoming an epidemic". At the UN 2016 General Assembly, the Special Rapporteur on the situation of human rights defenders Michel Forst expressed his concerns for the high violence against environmental defenders and acknowledged extractivist activities as a source of such violence and repression.

Given this grave and under-reported situation, this paper aims to address the issue of violence around dams. Violence and resource conflict is not a new topic in political ecology (Le Billon, 2014; Peluso and Watts, 2001) nor geography (Gregory and Pred, 2007; Springer, 2012; Springer and Le Billon, 2016). Further, several articles in this special volume address the issue in specific regions and across several types of conflicts (Navas et al., this feature; Teran, this feature). The novelty presented here includes the use of quantitative analysis to empirically establish the use of systemic violence to repress social opposition to dams. This points to a previously unexplored and concerning link between violence and renewable energies, particularly in an era of increasing renewable energy provision.

In this paper, we in turn aim to understand whether, through which forms, and against

\footnotetext{
${ }^{4}$ The analytical term 'Extractivism' commonly looks at materials extracted from local territories and exported across national boundaries, commodity chains and global trade (Moore, 2000; Gudynas, 2016). Electricity did not originally fall under these analytical lenses, or only when it serves mining activities, mineral processing plants, etc. However, if extractivism is understood as a mode of accumulation (Acosta, 2013) through activities that "remove large quantities of natural resources" to be sent far away, we need to question the role of renewable energy infrastructures to extract electricity. More, hydro infrastructure also disrupts other natural resources like water in its specific ecological cycle, causes deforestation, mines rivers beds, etc... The hydropower extraction frontiers and entire riverbeds become sacrifice zones devoted to extraction and generation, thus creating forms of dependence and exclusion of a certain section of the society and economy.
} 
whom violence and repression is today replicating around one of the new frontiers of renewable energy carrier production, i.e. hydropower. To do so, we ask three basic questions: i) who are the protesters in conflictive projects? ii) what forms of mobilizations do they employ themselves? iii) what forms of violence and repression do they face? We shed light on the profiles of those who are mostly targeted by violent repression, illustrate how opposition is expressed, and how it is repressed.

Studying violence and repression beyond a case study approach is not straightforward. It is not part of ex-ante impact assessments; it is often subjectively lived by those facing repression, but not necessarily publicly shared. Some forms of repression may also be subject to censorship and therefore not in the public eye. To address this challenge, we base our research on grounded knowledge, co-produced between academics and environmental justice organizations, which include empirical evidences, direct testimonies, published reports, academic papers documenting community's claims when faced with conflictive projects. We present an analysis of a unique database of $220 \mathrm{dam}$ related environmental conflicts, registered in the Global Atlas of Environmental Justice EJAtlas (Temper et al., 2015; Temper and Del Bene, 2016). To our knowledge, this is by far the largest database currently available on conflictive dams globally, constructed through co-produced knowledge.

Before presenting the results of our analysis, we briefly review the role of dams in relation to sustainability, as well as how the expansion of dams as renewable energy infrastructure is frequently justified by sustainability arguments, despite social opposition and corresponding violence (Section 2). Section 3 explains our methodology, the unique features as well as inherent limitations of a co-produced database, while Section 4 presents our results. We find that incidences of violence and repression are not uncommon in the establishment of large-dams and further that they disproportionately impact marginalized groups, such as indigenous peoples.

In the discussion section we highlight three main concerns and points of debate. We first suggest that co-production of knowledge should be largely encouraged in order to investigate sensitive topics in sustainability studies. Then, we argue that repression of the opposition against unwanted energy infrastructures does not only curb down specific protest actions, but also aims to delegitimate and undermine differing understanding of sustainability, epistemologies, and world-views. Worrying questions arise whether, where and how, the renewed interest into hydropower replicates patterns of violence in the frame of an 'extractivism of renewables'. Third, restricting our analysis to only at direct physical episodes of violence would be inadequate, as such direct forms of physical violence occur within a larger context characterized by indirect forms of violence, which include forms of structural and cultural violence (Galtung 1969) as discussed in detail in Section 5 .

With the new wave of investments in dams, we are concerned that also a new wave of violence is unfolding, as a deliberate strategy to make way for extractivist projects in an era of renewable energy provision.

\section{Background}

\subsection{Dams and Sustainability}


As we have introduced above, dams are back on the global development agenda (IHA, 2017). Zarfl et al, (2014) estimated that currently at least 3,700 hydropower dams $(>1 \mathrm{MW})$ are either planned or already under construction globally. Ninety-three per cent of this increase in production will be provided by 847 large dams with a capacity of more than $100 \mathrm{MW}$ each. Yet, dams are complex infrastructures and have triggered controversies between enthusiasts and sceptics for decades.

A vast literature addresses the severe environmental impacts dams generate at the local scale (Fearnside 2016, 2004, 1999; Grumbine and Pandit, 2013; Sovacool and Bulan, 2013). Scholars have also increasingly turned to implications of dam construction at regional and global scales. Examples include risks analysis for delta regions (Syvitski, 2008), hydrological alteration (Rosenberg et al., 2000) fragmentation of rivers (Zarfl et al., 2014), and greenhouse emissions of large reservoirs (Fearnside and Pueyo, 2012). Such a global perspective becomes particular relevant when discussing the effects of climate finance and the actual impact of dams on reducing emissions. Erlewein and Nüsser (2011) provide an evidence-based critique of the implications of institutionalized policies, such as Clean Development Mechanism funding for RoR projects, and question their sustainability as a means of mitigation. Scholars and activists point out that CDM funding for dams, along with an emerging uncritical 'small is beautiful' ideology are contributing to a green-washing of dam construction companies under the new banner of 'sustainable hydro' (Erlewein and Nüsser, 2011; Haya and Payal, 2011; Pottinger, 2008).

Concerning social impacts assessments (SIAs) used to assess dam projects, Kirchherr and Charles (2016) identify their limitations in properly grasping the complexity of dam impacts. This is attributed to a limited spatial and temporal perspective and overlooking interlinkages between impacts due to the fact that SIAs focus on the communities located at the construction and the resettlement areas, within a defined geographical boundary. For example, for decades the main focus of attention was the resettlement process and the political implications it inevitably unleashes (Cernea, 1997; Dwivedi, 2002). Displacement however is a much more complex social distress, and plays out along broader spatial and temporal scales. Beside the spatial dimension, 'project reductionism' (Erlewein, 2013) is evidenced by the narrow temporal frame applied to SIAs, when impacts are analyzed during only one specific phase (i.e. construction). Scholars warn that this short-sighted approach becomes legally relevant as it misrecognizes the planning and designing stage (Plummer Braeckman and Guthrie, 2016), or even politically and strategically sensitive when hydro plants are located close to international borders (Kuenzer et al., 2013; Middleton, 2012). Lastly, several scholarly reviews have found the governance of many hydro projects inadequate, leading to conflictive outcomes (Buechler et al., 2016; Kuenzer et al., 2013; Siciliano et al., 2016; Urban, 2014; Urban et al., 2015).

One of the most important and comprehensive studies on the controversial impacts of dams was published as early as 18 years ago. In 2000, the World Commission on Dams published its famous report, which on one side acknowledged the advancements in human welfare through dams and water resources management (in particular through multipurpose dams for their role in water management and irrigation, flood control and electricity generation), but came to the conclusion that large dams are both socially unethical and environmentally unsustainable (WCD 2000). The global effort of the commission was only possible thanks to the participation of both technical experts in the sector and the affected communities, and is still considered the most respectable global study. The results were so 'damming' that the sector went through a lull for several years, 
and several investments from the World Bank and other big financial institutions and companies were withdrawn. Since then, academic studies have continued to problematize large dams, while at the same time a more integrated approach to dam planning and water resources management has been consolidating. Yet, one decade later, the cautions laid out in the WCD report seem to have been drowned out and forgotten in international development politics, amidst a new flurry of excitement and investment in large-scale hydropower (Cole et al, 2014; Ahlers et al. 2015).

\subsection{Dams and violence}

The issue of violence related to dams and contentious opposition to them has been less addressed in sustainability studies. We acknowledge that violence may take many different forms, and that the concept has been extended to include forms of violence that are not direct and physical. Here below we touch on the relevant interpretations of violence with relation to environment and infrastructures.

Following Galtung's seminal contribution on the 'triangle of violence', which includes direct (physical), structural and cultural forms of violence (Galtung 1969), some authors have proposed complementary concepts for those contexts where violence is perpetrated especially through disruption of the environment. Paul Farmer (1996), for instance, contributed to the understanding of dam-induced displacement in Haiti in the 1960s as structural violence, by which social arrangements put individuals and populations in harm, and through which economically or historical processes constrain individual agency. Furthermore, Nixon (2011) proposed the concept of 'slow violence' to refer to environmental threats (climate change, desertification, etc) whose repercussions are dispersed across time and space and are therefore largely imperceptible and immune to rousing calls for action. 'Slow violence' becomes important to be considered when looking at the larger environmental and health impacts of dam projects. In relation to the territorial implications of large infrastructures, Rodgers and O'Neill (2012) have also discussed 'infrastructural violence' by looking at the role of infrastructures as the medium of structural violence and the place where power relations play out at the level of everyday practice. The authors draw on James Scott's suggestion that infrastructures are major vectors for the organization of society by the state (Scott 1998). These concepts and questions can be extended to the development of hydropower related infrastructure (dams, roads, power houses, transmission lines, etc) by asking, why do they become violent, for whom, under what conditions?

Direct violence (physical and intended to provoke physical harm) related to dam conflicts has been largely reported as domestic or motivated by communitarian/ethnic revenge, or a result of bad management of resettlement procedures, or lack of due information to the impacted families (Becker and Vanclay, 2003). Only few studies have looked at direct violence against protesters, such as for instance an analysis of 93 protest campaigns against water projects, including dams, between 1971 and 1992, during the authoritarian regime in Indonesia, where "protestors suffered costs ranging from minor intimidation to murder in over one-fifth of the cases" (Aditjondro and Kowalewski, 1994). For the complexity of gathering reliable global data on violent repression of protests, and maybe also due to the limited capacity by researchers in reaching out to communities on the ground, this topic has generally been less analyzed.

However McCully's book Silenced Rivers (McCully, 1996) and the World Commission on Dams (WCD) report both marked a watershed in addressing the issue of violence 
against dam opponents. While the WCD report is rather conservative in its language and data (McCully, 2000), it exposed and warned about violent actions against dam critics due to repression by either the state or interested parties. "Populations affected or threatened by dams have fiercely resisted dam building throughout the last century. [...] affected people's resistance to dams often went unnoticed internationally and, in some cases, the states concerned used intimidation and violence to suppress it" (WCD, 2000; p.18). The WCD illustrated this dynamic with examples such as the Kariba project between Zambia and Zimbabwe, the first WB-funded dam, where the colonial government in 1958 open fire on protesters, killing eight people and leaving 30 injured. (EJAtlas, 2015a). The commission recognized that "coercion and violence have been used against communities affected by dams” (WCD, 2000; p.218).

Both McCully's book and the WCD report relied on first hand data and testimonies from the ground up. The work of local groups, that we call here generally 'Environmental Justice Organizations' (EJOs), are often the main testament to the systemic pattern of violence and violation of human rights related to dam projects. Organizations opposing dams formed as early as thirty years ago, such as the Narmada Bachao Andolan (NBA) in India, or the Movimento dos Atingidos por Barragens (MAB) in Brazil; while others came together more recently, like the Movimiento Rios Vivos in Colombia, or MAPDER in Mexico. They share a common goal in unveiling the impacts of dams, building on a critique put forward for the first time by Goldsmith and Hildyard in "The social and environmental effects of large dams" (1984), a book that helped launch an international anti-dam movement (McCully, 1996). Their collective stories were published in the International Dams Newsletters since late 1985 (later renamed World Rivers Review), coordinated by those who then formed International Rivers. As a result of this first phase of movements' cohesion, the 1997 Declaration of Curitiba demanded a "halt to all forms of violence and intimidation against people affected by dams and organizations opposing dams" during the First International Meeting of People Affected by Dams (Declaration of Curitiba, 1997).

During over three decades of exchange, mutual learning, and international campaigns, the locally grounded knowledge of the global anti-dam movement has produced unprecedented documentation on violations of human rights and violence (see for example Censat Agua Viva and Mining Watch Colombia 2009; CDDPH, 2010; Centro de Estudio para la Democracia 2016). Also research and advocacy groups such as Global Witness and Frontline Defenders have systematically collected evidences of repression and assassinations of environmental defenders, many of them connected to dam projects (Global Witness 2015, 2016; FLD 2016). The analysis of this paper relies therefore on knowledge co-production between activists and academics, as described in the next section.

\section{Methodology: the EJAtlas, co-produced data sets, and proxies for violence and repression}

Our analysis is based on a global dataset of 220 cases, taken from the Global Atlas of Environmental Justice (EJAtlas, see www.ejatlas.org). The general objective of the EJAtlas is to identify emblematic cases of opposition and mobilization against environmental injustices and ecological distribution conflicts (see Temper et al., 2015 and the editorial of this SI for the overall methodology of data collection). Data for the 
entries were gathered together with local groups, independent researchers, scholars and journalists, within a framework of activist-led research and co-production of knowledge, according to their diverse and pluralist forms of knowing and with different grades of engagement (Brown, 1997; Fals-Borda, 1987; Jasanoff, 2004; Bremen and Meisch, 2017). As Escobar (2008) argues, these social movements are important spaces of knowledge production that do not only enact politics through protest and cultural contestation, but are generators or facilitators of diverse types of knowledge creation (see also Conde 2014, and Temper and Del Bene, 2016). Research using co-produced knowledge is generally based on single in-depth studies, as it is a time-consuming process between researchers, activists and/or affected people, but rarely draws on a comparison of a large number of cases. This paper is an attempt to do so, by providing new insights based on a global analysis.

To construct the EJatlas database specifically on dams, a total of around 100 collaborators were involved in a process that lasted over five years. They include leaders of relevant environmental organizations in their respective countries (e.g. Censat in Colombia, Accion Ecologica in Ecuador, MAB in Brazil, NAPM in India, etc), academic researchers and activist scholars, activists and community members in the affected areas. Most of them have been contacted directly by the authors, or through snowball sampling. As a first step, conflicts were identified according to their relevance in the country and the actors involved. The focus has been on cases where mobilization started from the early '90s, but includes also a few historical cases (like Akosombo in Ghana or Sardar Sarovar dam in India, for their emblematic impacts).

In a second phase, data on the conflict were added into the EJAtlas through a form of over hundred fields, containing both qualitative and quantitative data (on both the conflict and the conflictive project). Data were then revised and moderated by the authors to ensure quality and exhaustiveness, and finally made public on the map and open to public extended peer-review and comments ${ }^{5}$. To further validate our data, and to find specific information on repression, we also count on 24 testimonies from social movements leaders and communities, transnational NGOs, scholars, and advocacy groups, collected across several countries in the last three years. Due to their sensitivity, we are unable to disclose their identities. The analysed 220 cases represent thus a purposive sample that focuses on conflictive dams, and which has been constructed based on expert knowledge and elicitation.

\footnotetext{
${ }^{5}$ For a more general description of the data gathering process, see also Temper et al., 2015
} 


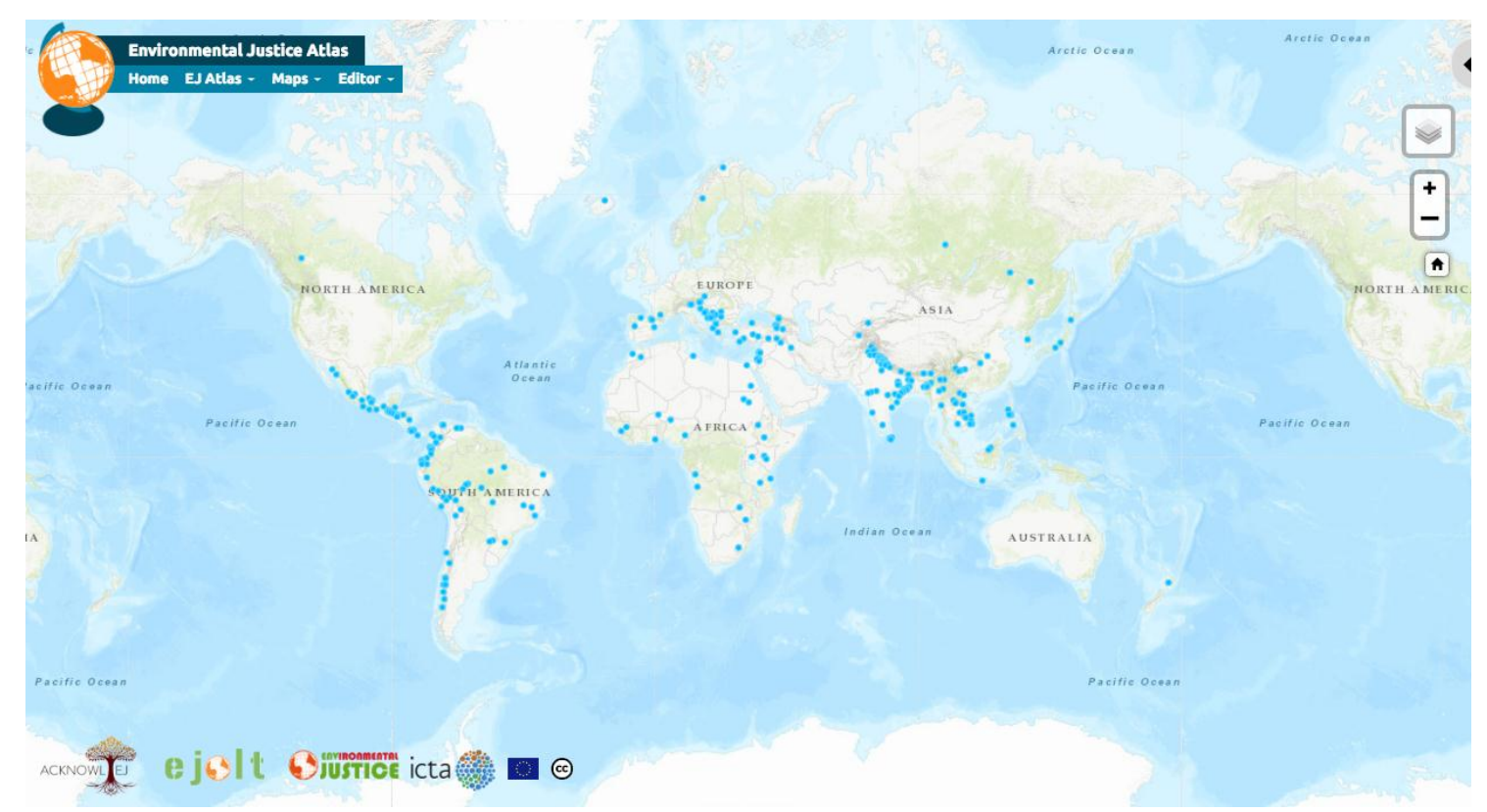

Figure 1: Global map showing the location of conflictive dam cases analysed in this paper. Note that lower presence of case does not necessarily mean there are no conflicts. Coverage largely depends on availability of data and accessibility to local informants.

To inquire into direct forms of violence and repression, we base our analysis on the following outcomes reported in the EJAtlas form: Repression of the protest, Criminalization, Violent targeting of activists, and Deaths through murder (RCVD). Repression (R) includes forced subjugation of protest, dissent or demonstrations. Criminalization (C) refers to a wide range of falsified or distorted accusations to discredit activist (often social leaders, spokespersons or acknowledged authorities, women, etc), start legal cases against them. Violent targeting (V) of activists is understood as direct actions deliberately aimed at harassing, injuring or killing specific targeted persons, usually key activists. Deaths through murders (D) refer deaths of project opponents either as a consequence of repressive actions during protests or through deliberative assassinations.

To inquire into forms of indirect violence, we discuss the most reported impacts, both visible (where written proofs are available, or reliable eye witnesses) and potential (with reasonable fear it could materialize for published technical reports, or for alarming signs of initial damage, for example) regarding environmental, socio-economic and health issues and discuss how they relate to other forms of violence beyond direct physical violence. The quantitative analysis presented is further complemented with qualitative, anecdotal information from specific cases and interviews.

Note that the sample presented by the EJAtlas has some inherent limitations. Global case coverage depends on collaborators willing to contribute to the EJAtlas. Hence, data availability is limited and the obtained sample, visualized in Figure 1, has an uneven geographical coverage. Therefore, no country comparisons can be made, but only basic conclusions across the total set of conflicts, and regarding broad geographical regions that are sufficiently mapped. As seen in Figure 1, the discussed cases are primarily concentrated in South and Southeast Asia, Central and South America, Balkans and Anatolia. Other regions like many African countries, China, and Russia have a lower number of cases because of our difficulty in getting information from these areas. Other 
regions such as North America and Europe also have fewer cases analyzed as many dam related conflicts there happened much earlier than the time period considered. Hence, while we do not claim this sample to be statistically representative at the global level, the number of 220 cases represents the largest empirical review on conflictive dams based on co-produced knowledge, available until today in the literature. Therefore, it can provide new important insights into the wide-ranging characteristics of conflictive dams.

\section{Results: protester groups, resistance strategies and violence}

We turn now to discussing the results of our analysis on the use of violence and repression across conflictive dams. At the outset, it should be noted that among the categories of industries the EJAtlas documents, including mining, nuclear, fossil fuels extraction etc., water management conflicts such as dams are among the most intense and conflictive, in terms of degree of mobilizations and violence involved (EJatlas, 2017). The following subsections provide the results of the quantitative analysis regarding the different opposing groups involved in these conflicts, their forms of mobilizations, and the different forms violence and repression they face.

\subsection{Groups mobilized in dams conflicts}

Figure 2 shows the frequency of diverse groups reported to be at the forefront of opposition. We subdivided the protester groups into four main categories: 1) local protesters, largely concerned about livelihood issues; 2) institutionalized and organized groups; 3) frequently discriminated groups and 4) other occasional groups. Note that these groups are not mutually exclusive, as protesters may share the characteristics of various groups (like e.g., indigenous farmers). 


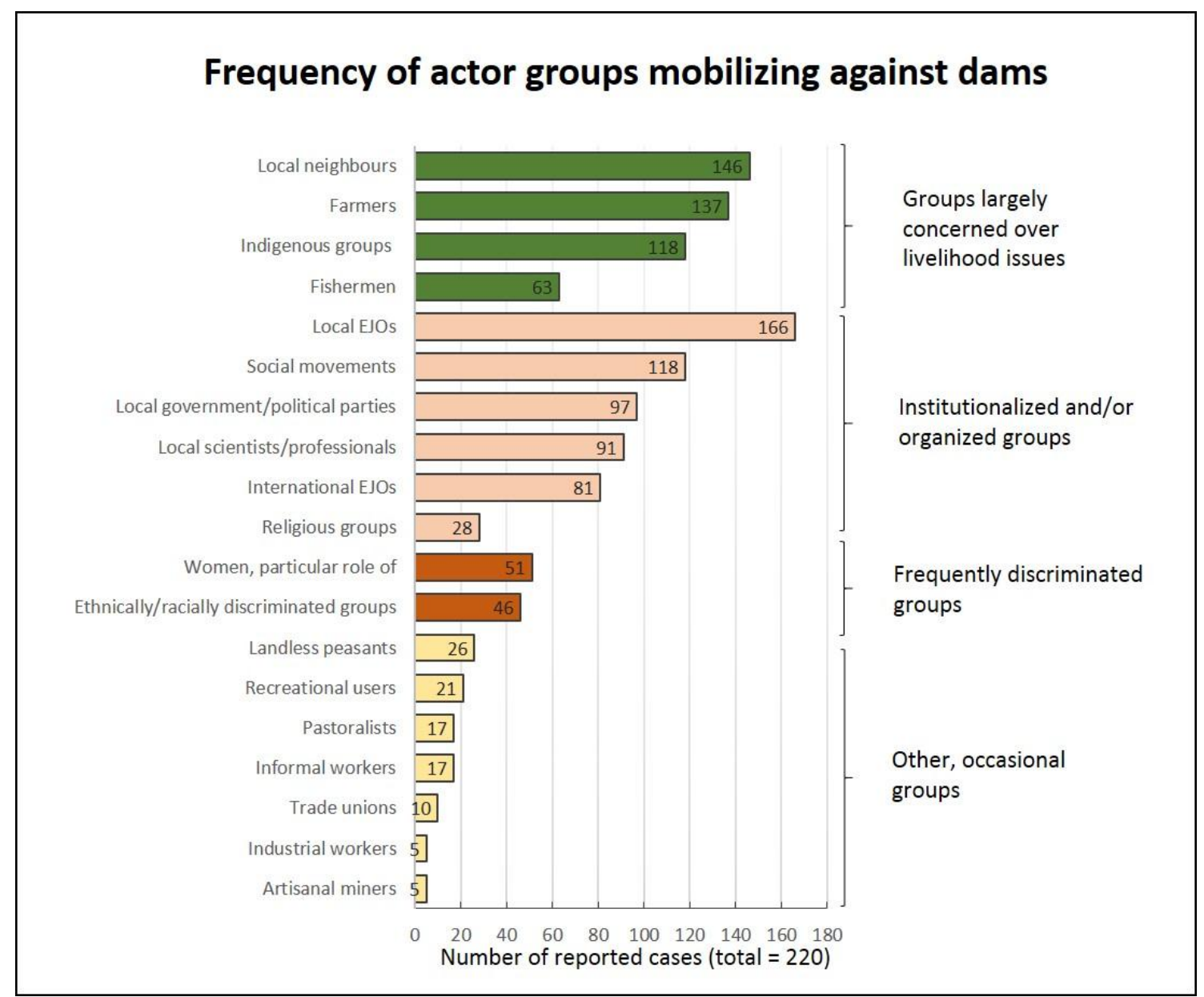

Figure 2: Frequency of actor groups mobilizing against dams. Source: own elaboration, based on a sample of 220 cases of conflictive dams, retrieved from the EJAtlas database. Categories are taken from the EJAtlas form. Note that categories are not mutually exclusive, i.e. one case commonly involves several groups, and individual protesters (e.g. an indigenous farmer) can belong to several groups.

In contentious activity related to dams, 'local groups largely concerned over livelihood issues' appear to be the ones that most mobilize. This category includes local neighbours, farmers, Indigenous communities and fishermen. They represent a manifestation of what Martinez-Alier (2002) calls the Environmentalism of the Poor, as hydroprojects have a severe and irreversible impact on their means of livelihood leading to their impoverishment.

The issue of loss of land and means of livelihood due to submergence is a key reason for farmers to mobilize, but they also do so to resist forced broader agrarian changes dams would bring along, including transformations of land use patterns, transfers in land property, increased industrialization, etc. The 'water grab' (Franco et al., 2014) element in agrarian conflicts is often further aggravated by the submergence of riparian land with very rich nutrients, that represents a grave loss for local economies and subsistence. The Akosombo dam built by Impregilo in 1961 in Ghana, for example, flooded a huge area of the Volta River Basin (creating one of the largest man-made reservoirs, the Lake Volta) and displaced over 80,000 farmers, in the name of the largest development intervention in the country (McCully 1996, EJAtlas 2016c). This inevitably leads to increased agrarian conflicts as a result of land shortage. 
Indigenous communities are one of the most mobilized and impacted groups, due to the large amount of indigenous territories in old and new extraction frontiers of hydropower (Fearnside, 2015; Huber and Joshi, 2015). Almost all large dams in the Philippines were proposed or finally built on indigenous territory (WCD 2000). In India, tribal people represent just $8 \%$ of the population but $40-50 \%$ of those displaced by dams and other development projects (Survival International, 2010). Indigenous peoples, along with fisherfolk and informal workers, are also the ones that have been mostly misrecognized by ESIAs, when not accounted for at all for lack of written entitlements, discrimination, racism, among other factors.

The category of 'Often discriminated groups' deserves a special note. They are usually not recognized as affected peoples, as they usually don't have written legal entitlements to land. We have discussed this already for fisherfolk above, but it is also particularly problematic for unmarried women or widows (and their children) (Interview with lead activist, December 2015. India). The impacts on their livelihoods remain overlooked and often uncompensated. In almost a quarter of all cases, women turn into leading figures in dam protests.

The graph shows a very high percentage of cases where communities have organized into collectives, social movements, local organizations, formal NGOs, etc (local EJOs and social movements). Such collectives represent an important social actor and are representative of what Martinez-Alier et al., (2016) call the global Environmental Justice Movement. This is in fact to be found across the five continents and with common demands, although with differences in terms of level of engagement and capacity of networking between organizations (higher in Latin America for example, lower in African countries).

The involvement of international organizations to support local protest is found in 81 out of the 220 cases. This figure is not high when we consider that the sample includes primarily the most contentious projects known internationally. This involvement is most prominent when international companies as well as finance institutions like the WB and other funders are involved, leading to coordinated actions between local groups and others located in the countries of origin of the investment. This figure is particularly relevant if we consider the recurrent efforts project proponents and governments make to criminalize protestors as foreign-led conspirants, 'anti-development' enemies who want to keep impoverished countries poor. This was for example the case for the NBA campaign in the Narmada valley in India to stop the Sardar Sarovar dam and other projects in the same basin (EJAtlas 2016d and EJAtlas 2016e). Other social movements (whose main activities might be related to other social justice issues such as health, education, housing), religious groups, local administrations and scientists are other important actors, which prove the broad scope of the resistance, and the plurality of concerns it mobilizes.

\subsection{Action Repertoires}

Figure 3 shows the large repertoire of mobilization forms. We highlighted four main features that characterize them: non-violent and largely informal actions; actions that intervene in formal procedures; creation of alternative knowledge; actions with a potentially violent character. 


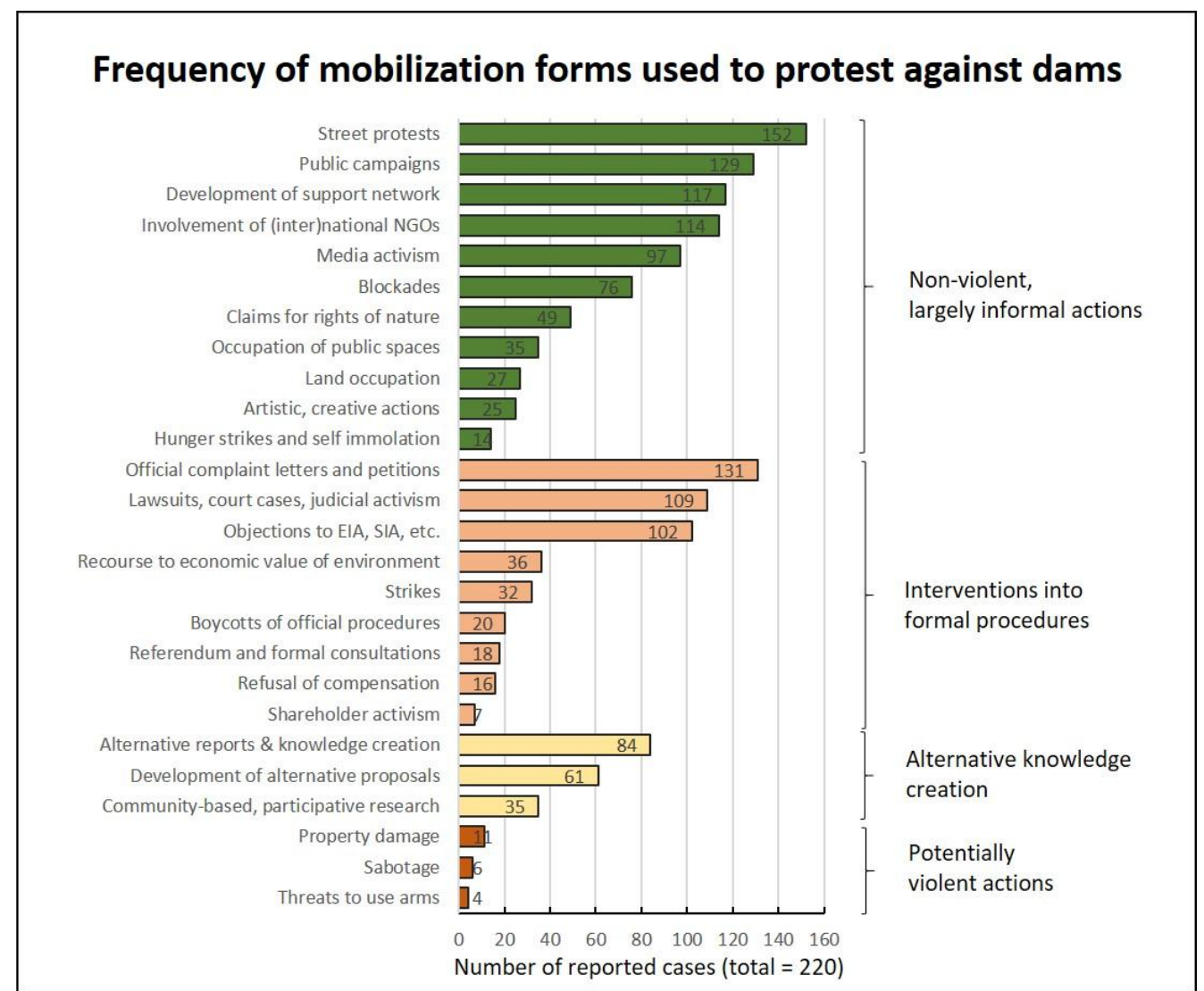

Figure 3: Frequency of mobilizations forms reported to be used to protest against dams. Source: own elaboration, based on a sample of 220 cases of conflictive dams, retrieved from the EJAtlas database. Categories of forms of mobilization are taken from the EJAtlas form.

According to the information on organized resistance we have access to ${ }^{6}$, expressions of dissent and resistance are primarily non-violent and in the public domain (street marches, open petitions, artistic performances etc.). Violent actions remain extremely marginal. Nonviolent resistance also includes more disruptive actions where people have put their own bodies in the frontline of resistance, i.e. during land occupations or blockades, which often happens when no other means prove effective or was heard. Similarly, hunger strikes and self-immolation (or threats thereof) were also adopted in a desperate effort of making one's claims recognized while at the same time not giving up to violence. Perhaps the most powerful and evocative protest action is the 'jal samparan', taken by those whose homes were threatened to be submerged by the Narmada dams in India. Here, protesters have been staying in rising waters after the closure of dam gates and were ready to be drowned in the water if no action is taken in their favour (Baviskar, 1995). These extreme actions show the determination of not being wiped away by imposed megaprojects and the deep attachement to one's territory, and testify to the undemocratic character of dams related extractivism.

Beside direct resistance actions, anti-dam movements are increasingly building alliances with other sectors or social movements, broadening the scope of their construction of alternatives. This shows that opposition actions are not only confrontational, but increasingly propositional and proactive towards systemic changes. The Brazilian MAB is for example allying with trade unions in the Plataforma Operária e Camponesa para

\footnotetext{
${ }^{6}$ Our database does not generally account for individual initiatives that fall outside a collective strategy of opposition, information to which we would not necessarily have access.
} 
Energia (Workers' and Farmers' Platform for Energy) ${ }^{7}$, to discuss the historical debt that megaprojects and energy corporations owe to those affected, and to draw-up their proposal for an energy and mining policy for the country (Proyecto Energetico Popular). Similarly, the Colombian Rios Vivos Movement is pushing for a Modelo Social MineroEnergetico, as an alternative agenda to the government's energy and mining policies. Such building of a support network, whereby organizations or NGOs at the national- and international level work together on a common agenda, is to be found in over $50 \%$ of the cases.

Almost equally used are forms of political advocacy that intervene in official procedures, such as official petitions, the application of legal tools (both in national and international courts) to counteract flawed ESIAs, official compliance letters in order to defend affected peoples' rights and demand environmental regulations are judicially applied. Such type of action testifies to a high level of capacity and the knowledge necessary so as to be able to engage with what are often complicated and expensive procedures. It also demonstrates the high incidence of projects that are suspended or rights recognized via legal mechanisms, which suggests that projects are often pushed forward in not complete compliance with the law. Consultations and legal referenda have become increasingly important in some regions, especially in the indigenous territories of Latin America, where consent from the communities is recognized by national and international law (Convention 169 of ILO, the United Nations Declaration of the Rights of Indigenous Peoples, etc.), although not always enforced. Consultations have asked for the cancellation of projects such as the San Mateo Ixtatán dam in Mexico (EJAtlas 2017c), or the Corpus Christi dam, between Argentina and Paraguay (EJAtlas 2017i), which led to the scrapping of the project in 2014.

We observe that apart from confrontational actions and engagement with official procedures, mobilizers have also created spaces for alternative knowledge production. This includes reports and community-based participatory studies, for example to detect specific impacts, or to denounce repression against the communities. It also includes studies on the viability of energy alternatives and sustainable uses of natural resources, or spaces for community-based psychological assistance and rehabilitation (see further in the Discussion section).

\subsection{Repression, Criminalization, Violent targeting, and Assassination of dam opponents}

Figure 4 shows the percentage of incidences of repression, criminalization, violence against activists and death through murder (RCVD) across the global database and where specifically indigenous populations are involved.

\footnotetext{
${ }^{7}$ See more at: http://www.mabnacional.org.br/category/tema/plataforma-oper-ria-e-camponesa-paraenergia
} 


\section{Repression, Criminalization, Violence and Death through murder}
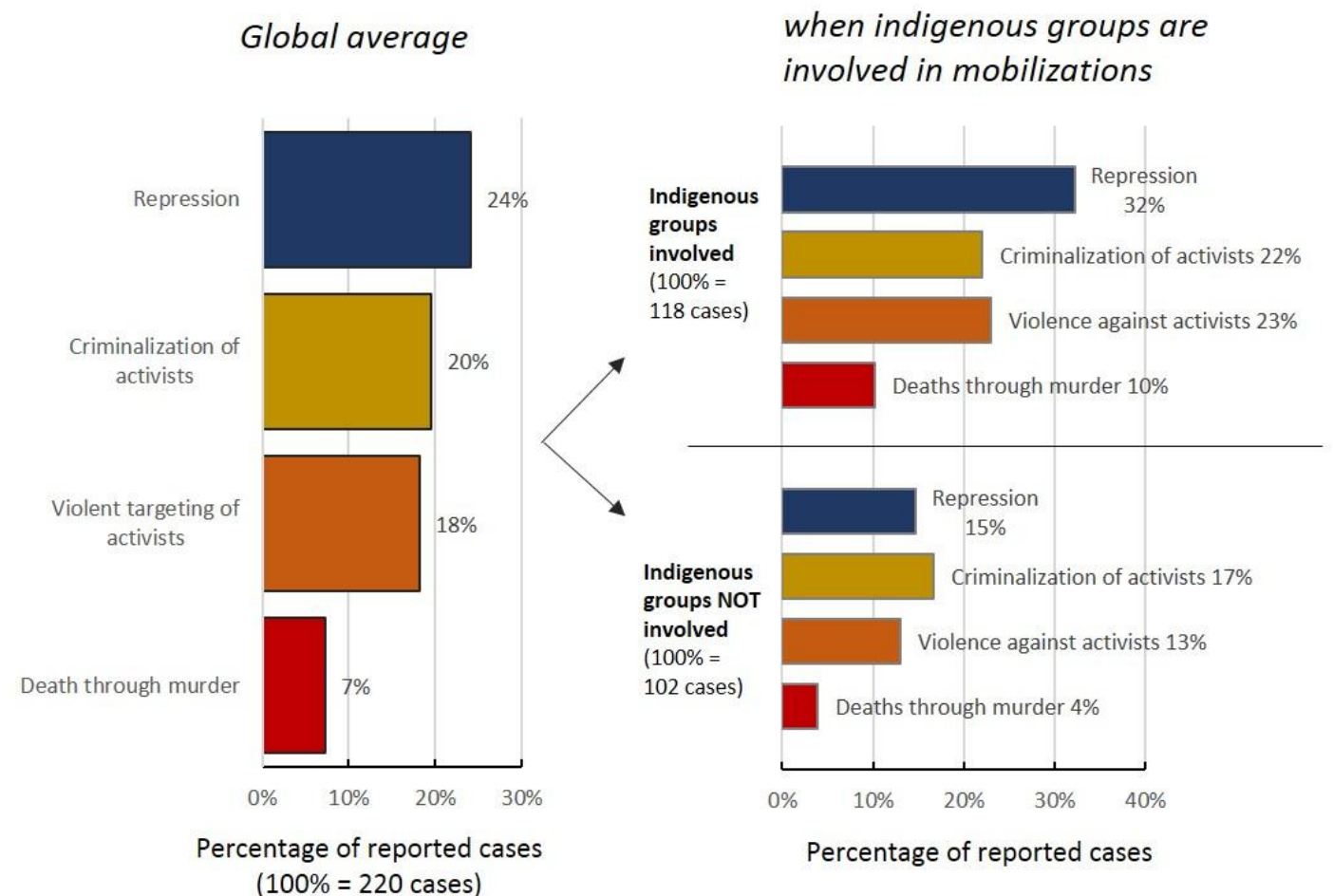

Figure 4: Rates of repression, criminalization, violence and death through murder, faced by protesters against dams. Source: own elaboration, based on a sample of 220 cases of conflictive dams, retrieved from the EJAtlas database. Indigenous groups were reported to be involved in mobilizations in 118 cases, out of the total sample of 220 cases. Categories are taken from the EJAtlas form.

Some stories from the ground may help to illustrate how incidences of RCVD manifest in practice, often in an interrelated way. Repression is a broad category that captures physical repression of dissent, either during protests and actions, but also through militarization of an area, police presence, curfews, etc often targeting a whole community/group. The company Hidro Santa Rita in Guatemala is responsible for fostering repression and intimidation of communities along the Río Dolores (EJAtlas 2016h). In 2013 forced evictions started and arbitrary detentions were used to silence the opposition. The conflict escalated and in 2014 two teenagers lost their lives and many more were brutally attacked with machetes during a Catholic celebration. Despite this, the project received CDM funds that same year (ibid).

Criminalization was also found to be an extremely recurrent tool for discrediting and silencing dissent. It can occur through judicial means, such as lawsuits against activists and EHRDs, but also through the construction of discourses that aim to delegitimate project opponents, and their organizations. Governments often accuse them of being antinational, anti-development or even terrorists, and therefore intimidate them. Private actors too may abuse the law against them, for example through defamation or libel lawsuits, or cases of property damage, trespassing, and the like. That way, powerful entities such as states and companies may place restrictions on civil society activities, while increasing the burden on activists with litigation costs and damages they may be 
unable to deal with and which curtail their capacity to organize. For example, in the case of El Quimbo dam in Colombia, leaders of ASOQUIMBO have been sued for strikes, land invasion, obstruction of roads, and personal injuries against police forces (EJAtlas, 2017a). However, in April 2017, the Supreme Court finally rejected similar accusation attributed by ENEL/ENDESA to two of the leaders (Interview with activist scholar, October 2016. Colombia)

The case of Margarito J. Cabal in the Philippines is evocative of the link between criminalization and violent targeting of leading activists and key personalities in the community/movement, sometimes carried out by the police forces as well as through private security guards, or even hired assassins. Margarito was a member of the Save Pulangi Alliance, involved in the opposition to the Pulangi V hydroelectric project in Bukidnon province, which would submerge 22 villages, including indigenous peoples' land and small farms. The accusations against Margarito were accompanied by repression of the movements' meetings and threats to other members. In this context of highly conflictive and unpunished violence, Margarito finally lost his life in 2012 by the hands of two unknown men.

Our results show at least 20 cases where activists or opponents to dams were murdered either during peaceful actions, public demonstrations or at their own homes. In Mexico, the case of Noé Vasquez, an activist opposing the Naranjal project on the Rio Blanco (EJAtlas 2016g), triggered outrage in 2013, just before the opening ceremony of the 10th National Meeting of the Mexican network MAPDER, in the state of Veracruz. He was collecting flowers and plants in a nearby forest for a Xochitlalis ritual to thank Mother Earth and remember all the victims of extractivist projects, when he was shot dead. The murder of Berta Caceres and numerous indigenous activists related to the Agua Zarca project in Honduras (Centro de Estudio para la Democracia 2016; EJAtlas, 2016a) is another case in point that demonstrates the inter-connections between dam projects proponents, military elites and hired assassins, to get rid of uncomfortable movements' leaders ${ }^{8}$.

Globally, repression appears to be the most recurrent tool for silencing opposition, followed by criminalization of activists, violently targeting them and assassinations. However, disaggregating the data into dam conflicts in which indigenous groups were involved in mobilizations (118 cases), and those they were not (102 cases), the way violence and repression are employed changes. While in non-indigenous territories, criminalization is the most recurrent form of curbing opposition, followed by repression, violent targeting and assassination; in indigenous territories, repression increases significantly (from $24 \%$ of cases in the global database, to $32 \%$ ) and becomes the most frequent one, followed by violent targeting and criminalization. Incidences of assassination also increase to $10 \%$ of cases when indigenous communities are involved, compared to $4 \%$ when they are not. Note that one conflict case can have several victims. This shows two important aspects. First, it demonstrates the higher level of direct violence present in indigenous territories, which have become important frontiers of dam construction. Second, the continuance of historical racism against indigenous communities as well as the impunity of crimes committed against them in a context of ongoing colonialism. Global Witness' database on environmental activists killed reflects

\footnotetext{
${ }^{8}$ Evidences are reported by lead lawyers of the case, more details here: https://www.theguardian.com/world/2017/feb/28/berta-caceres-honduras-military-intelligence-us-trainedspecial-forces. Last accessed: 30.11 .17
} 
this, with at least 47 of the 116 EHRDs killed globally in 2014 indigenous. In 2015, the number increased to 67 out of 185 (Global Witness, 2015). Moreover, indigenous peoples often face other severe challenges, linked with the failure of governments to recognize (collective) ownership rights vis-à-vis ancestral lands. Resulting legal ambiguities in turn facilitate labelling of activists as criminals when they resist unwanted projects (Interview with threatened movement organizer, November 2016. Mexico).

This data presents evidence to, on one hand, the wide array of territorial and social implications extractivist industries such as dams provoke, ranging from irreversible pollution and depletion of resources, to displacements, militarization, racism, division of communities and families, machismo and violence against women, to the wiping out of indigenous knowledge, among others. On the other, it also shows the political meaning of repression of protest. What these people represent for the movement and the nature of their militancy shows that what is at dispute on the ground is not only the construction of a (dam) project, but also the delegitimization of dissent and differing political and life projects and understandings of sustainability (Escobar, 2008; 2014). The next section discusses the wider context in which violence and repression occurs, including forms of indirect violence.

\subsection{Environmental, Socio-economic and Health related Impacts}

Violence cannot be understood solely as isolated episodes, which occur against individuals in an otherwise 'normal' environment. Assassinations, violence, repression and criminalization commonly happen in an already suffering environment, where resources are overexploited and their capacity for regeneration undermined. This section examines the most common environmental, socio-economic and health related impacts recorded in our database (Figure 5) so as to bring forward insights on the profound consequences of the hydro industry in an integral manner. 


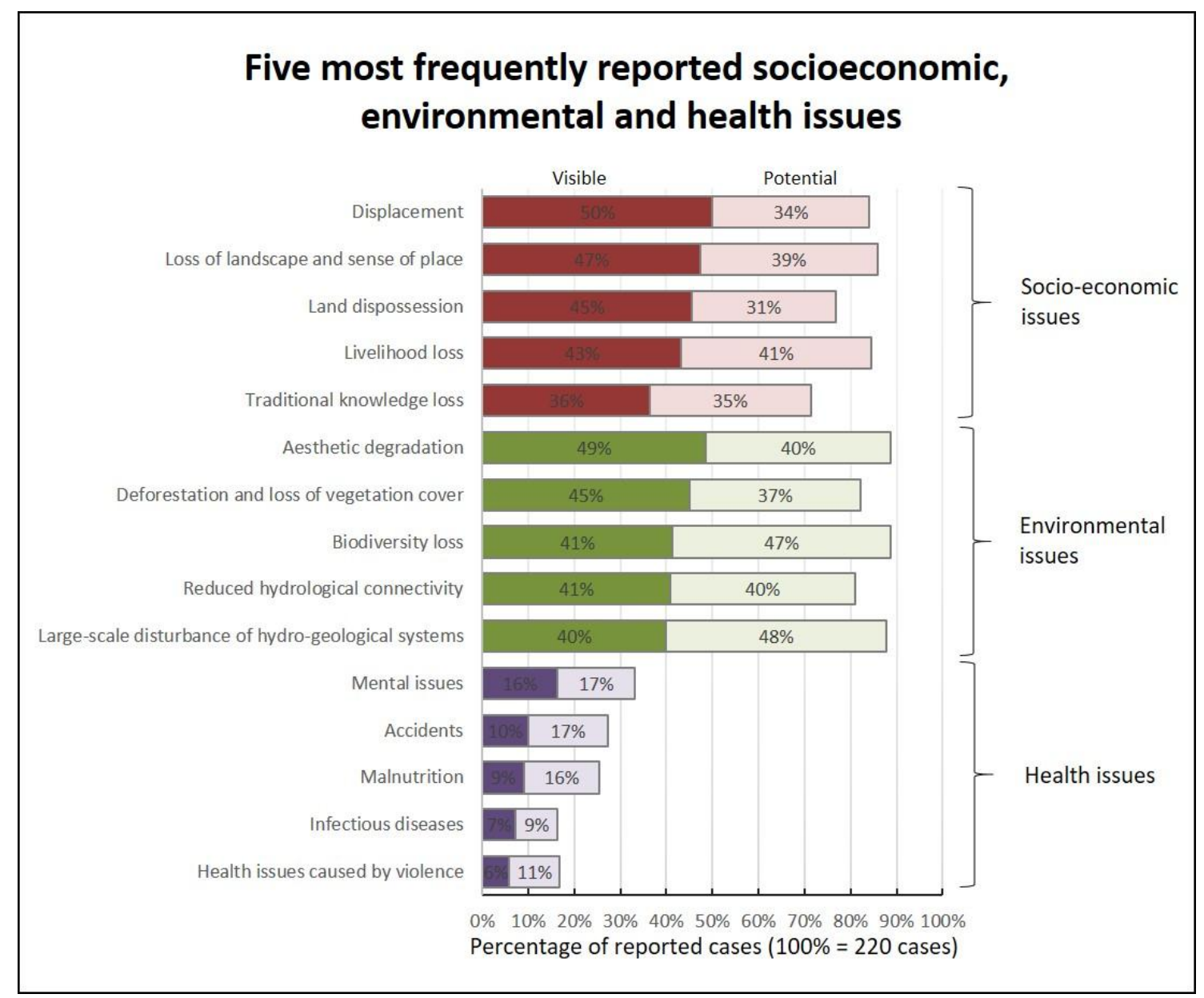

Figure 5: Five most frequently reported visible and potential socio-economic, environmental and health impacts, provoked by conflictive dams. Source: own elaboration, based on a sample of 220 cases of conflictive dams, retrieved from the EJAtlas database. Categories are taken from the EJAtlas form.

Of reported socio-economic impacts, the five most recurrent categories are 1) displacement, 2) loss of landscape and sense of place, 3) land dispossession, 4) loss of livelihood, and 5) loss of grounded traditional knowledge. Such impacts usually entail an important loss of grounded traditional knowledge. These are among the prime reasons people mobilize, as seen above in Section 4.1. In our sample, 38-50\% of cases are already experiencing these impacts, termed visible, whereas in up to $70-85 \%$ of the cases these impacts are considered potential if the project goes through. Induced displacement, land dispossession or grabbing, and loss of livelihoods, might also happen long before the implementation of projects, when resistance is less intense (Interview with movements organizer, October 2016. Colombia). However, as in the case of the Sardar Sarovar Dam along the Narmada, threats of submergence can be used as an illegal tool for forcing people to move against their will and against the law, even without providing a proper resettlement site for them (Interview with lead activists, April 2014. India) ${ }^{9}$. Forced evictions can also happen under violent circumstances whereby violations of human rights (understood here mainly strictu sensu as violation of personal freedom and integrity) are no exception.

\footnotetext{
${ }^{9}$ At the time of writing, over 40,000 families in the Narmada valley are under serious threat of drowning in the area of the Sardar Sarovar dam. Authorities are determined to close the gates despite resettlement being not fully done and infringing this way the orders of the Supreme Court.
} 
The previously cited Kariba case is an eloquent example from the ' $50 \mathrm{~s}$, but forced evictions by paramilitary gangs also occured at Chixoy dam in Guatemala in the '80s (EJAtlas, 2015b); since 1989 over 40,000 Guaranís living on the border between Paraguay and Argentina were forcibly evicted to make way for the construction of the Yacyretà Dam (EJAtlas 2015c), including the burning down of houses, the flooding of farms and homes without prior notice. Since 2008, over 80,000 people in the river Cauca valley in Colombia have been evicted to make way for the Urrá and Hidroituango dams. Here, military and paramilitary forces are key actors of violence and forced evictions (Interview with community members, October 2016. Colombia). The movement Rios Vivos in Colombia and Censat Agua Viva, and Burma Rivers Network warn of the escalation of militarization as a tool for expansion of extractivist economies in such countries affected by internal armed conflicts, and in volatile ethnic borders regions (Censat Agua Viva and Mining Watch Canada, 2009).

Visible environmental impacts are reported for about $40 \%$ to $50 \%$ of the conflict cases, including some plants that are still under construction. Aesthetic degradation and loss of vegetation cover are the most observed, while loss of biodiversity and disturbance of hydrology are also common direct consequences. This percentage rises to $80 \%$ to $90 \%$ if we count also the cases where these impacts are deemed as potential. Deterioration of the environment, be it due to visible disasters and events, or through much slower processes of degradation of river- and adjunct ecosystems, may affect the basis of livelihoods and the health of many communities over the long-term (Interview with NGO affiliated ecologist, October 2016. Georgia). This issue can be understood as a form of 'slow violence' (Nixon, 2011; Holterman, 2014) that local communities face. As we showed above (Figure 2), these are among the groups that most mobilize.

Health implications should also receive high attention. Although the percentage of cases with visible (between $7 \%$ and $17 \%$ ) and potential impacts (20\% to 32\%) are lower, such impacts show the degree to which such projects disrupt and harm local communities. High levels of psychic disorders and stress, for example, have often been observed around dam construction, which can lead to depression and extreme actions such as suicide. In Chile, the tragedy of the Biobio river is a case in point, and sadly described as a "robbery of the soul"10. At the beginning of the "90s, soon after the Pinochet dictatorship, the company Endesa was planning to dam $180 \mathrm{~km}$ of river flow with six hydro plants in the Alto Bío Bío region. After a 7 year-long resistance of local Pehuenche indigenous communities, environmental groups and scientists, the company could only manage to build two, Ralco and Pengue (EJAtlas 2016f). However, it left behind 4,000 $\mathrm{km}^{2}$ of forests inundated and destroyed. This region now has the highest rate of depression and suicide of the whole country, aggravated by a high rate of deforestation and industrial plantation, industry and contamination, and new hydro projects like Angostura (EJAtlas 2017b). This case is one example of how widespread persecution and severe degradation of the territory can lead to psychological disorders, severe anxiety and depression.

\section{Discussion}

This paper has analyzed 220 cases of civil society mobilizations against dams and

\footnotetext{
10 Full testimony of Chilean ecologist and Right Livelihood awarded Juan Pablo Orrego can be found here: http://blogs.cooperativa.cl/opinion/medio-ambiente/20120719181008/alto-bio-bio-el-robo-del-alma/
} 
responses to them. This represents the first quantitative analysis of its kind to shed light on the nature and shape of dam conflicts, including the actors mobilizing; the social, environmental and health impacts that motivate their opposition, the forms their mobilization takes and state and corporate responses to their contention.

\subsection{Systemic repression}

We have shown that many hydropower projects are highly conflictive, and most significantly that opposition to these projects is routinely repressed with violence. While the social and environmental costs of dams themselves have been amply documented and are meant to be captured through ESIAs for individual projects, this paper provides empirical evidence of the often hidden but systemic crimes related to conflicts over dams themselves, establishing the high levels of violence and repression that are often entailed in pushing through such projects.

While such patterns of violence and militarization have been well documented as a key feature of extractivist projects, for example by Peluso and Watts (2001) for oil, what we show here is that such forms of repression, criminalization, violent targeting and assassinations employed against activists are also common features in the establishment of supposedly "sustainable" large-scale renewable infrastructures.

Given the extent of direct and indirect violence for conflictive dams presented, and the fact that these cases are not restricted only to countries under dictatorships and corrupted regimes, but are prevalent in democracies, as seen for example in Brazil (Milanez, 2015) India (Amnesty International India 2017) and France (Ejatlas, 2014), the data suggests that such repression and violence cannot be considered as rare cases of bad management but that such incidences are a systemic practice.

In non-Indigenous territories, criminalization of individuals or organizations and movements appears to be the first strategy to curb down dissent. However, in Indigenous territories, repression of protest actions or other forms of dissent becomes the most frequent one. Is this due to the dangerous condition where the abundance of unexploited natural resources, state and corporate impunity, and historical racism continue to replicate conditions of colonialism? Violence and repression appear to be a deliberate strategy for 're-ordering the territory' to make way for megaprojects (Ceceña, 2009). Such violence occurs in an atmosphere of impunity through the 'othering of local communities' and the framing of extractivist plans as necessary by governments and companies and executed by military and paramilitary (Escobar, 2004; Andreucci and Kallis, 2017).

Renewable projects, despite the claims of being carbon neutral and green, form very much part of the 'epidemic' UN expert Victoria Tauli-Corpuz talks about, in the economic and energy model of extractivism and mega-infrastructures. This leads us to suggest that large-scale dams can be considered a form of what might call 'renewables extractivism'. Sustainability studies are urged therefore to inquiry more in depth into how violence, repression and criminalization of dissent operate as deliberate tools to delegitimize different views and to impede transformations to and protection of sustainabilities.

\subsection{Pluralist worlds and other sustainabilities}


Our emphasis in this paper has been on the more direct and visceral forms of physical violence, however it is clear that such repression and violence have to be understood within the broader context of indirect forms of violence, including the severe ecological, socio-economic and health impacts presented which undermine livelihoods and ecologies, also termed 'slow violence' (Nixon, 2000). Resistance against dams by local communities, often together with other environmental justice organizations, political bodies, scientists, exposes the incompatibility of extractivist projects with the cultural and spiritual reference systems embodied in the territory.

If we take seriously the assertion that conflicts are a space where transformative alternatives may take shape (Scheidel et al., this feature; Temper et al., this feature), it becomes apparent that as violent repression targets resistance, it also undermines the emergence of alternative visions, epistemologies, world-views, the 'pluriverse' (Escobar, 2008, 2017; Shrivastava and Kothari, 2012). This silencing of other ways of being and other understandings of sustainability has led activists to term this sort of repression as 'extractivist violence"11.

The manifestation of extractivist violence in renewable energy projects highlights the need for further debate on the social impacts of 'transitions towards sustainability', and particularly of renewable energies (Avila, this issue), and on what sustainability actually means, what it is supposed to actually sustain. If we consider the communities opposing dams not as protestors but as protectors of other life sources and ways of life, we would see in them embodied witnesses of other understanding of sustainability. Anti-dam movements are creating collective visions on the type of energy model needed, energy for what, and controlled by whom. The Declaration of Temaca (2010), born out of the third international meeting of anti-dam movements in Mexico, for example, recognizes that resistance, protection and reconstruction (e.g., of local community-run energy generation plants, water harvesting and sanitation infrastructures, etc.) must go together. More initiatives to define forms of 'energy sovereignty' are under discussion in many countries, from Colombia (Movement Rios Vivos) to the USA (Trade Unions for Energy Democracy), from Germany (Energiewende) to Brazil (Movimento de Atengidos por Barragens), from India (Energy Vikalp Sangam) to Spain (Xarxa pr la Sobirania Energetica), and address both the rejection of specific projects and energy models and the construction of different economic and social bonds. This suggests that the making of a global or globalizing (Sikor and Newell, 2014) environmental justice movement around dams is happening not only across sectors but also across scales and countries, in a process we can call of scaling out, i.e. reaching out to and inspiring other similar movements.

\subsection{Co-produced knowledge for transformation}

The renewed interest in hydropower leads to concerns about a potential increase in the number and intensity of violent instances related to large-scale renewables as a panacea to the energy and climate crisis. Roadmaps for energy transition are urgent, but they

\footnotetext{
11 In December 2016, anti-extractivist networks launched an open online petition to the Ecuadorian government to call for stopping violent repression against the Shuar indigenous group in the Amazon and the persecution of the organization Acción Ecologica ${ }^{11}$. The petition called this "extractivist violence", to expose the strict connection of repression with the material extraction model. The petition can be found here:

http://movimientom4.org/2016/12/urgent-action-to-stop-double-persecution-against-shuar-communities-and-accionecologica-ecuador/
} 
cannot replicate the same system of political, technological, and epistemological control of the fossil fuels based economy. The design and evaluation of these new scenarios in turn require co-production of knowledge between academics, activists and affected people.

Environmental justice struggles are a place where colliding visions and understanding of life, economy, democracy, etc. confront each other (Escobar 2008). They are also a space of production between different forms of knowledge, in what is often called 'citizen science'. This research is founded in the recognition of social movements not as objects to be studied yet as creators of knowledge, often born out of struggles. Restoring their agency to set priorities in research agendas contributes what has been termed epistemic or cognitive justice (Grasfoguel, 2016). Such an approach involves going beyond research questions such as how to assess impacts, or how to facilitate a transition to renewable energies, to new understandings of what energy, water management, violence, security, sovereignty or democracy mean to diverse communities (Hildyard et al., 2012; XSE, 2018).

The EJAtlas is a product of such an effort that allows the gathering of information that otherwise remains invisible (Temper and Del Bene, 2016; Temper et. al., this feature). However, we recognize that the challenge is huge and that this database cannot be considered exhaustive. Many territories and resisting communities still remain in the shadow. Their stories finally get to the press only when known leading activists are murdered. How many other stories remain untold, invisibilized? In how many more ways violence unfolds and is experienced? What impacts will violence leave behind on the ground, which is not captured by any report, any press or scientific article?

Research requires new forms of engagement between researchers by profession (academics) and those who embody such grounded knowledge. How to pursue a robust scientific research, while at the same time acknowledging sensibilities and sensitive information? How to co-design and be active part of an engaged research throughout the process, even when timings can differ or different priorities being set (Temper and Del Bene, 2016)? How not only to co-produce, but also co-learn, co-comunicate, and cobenefit? How, for example, how shall scholars disseminate results beyond academic journals, in order to be influential or put pressure to governments, corporations, courts, as well as being relevant for marginalized and less accessible communities. Will this process finally challenge power structures in research production and respond to the call for 'utopian approach' in research methodology (Bell and Phal, 2018)?

A new political engagement of academic scholarship urgently needs to deal with the growing global repression against environmental defenders, the high complexity in knowledge production around sensitive topics, and ethical issues in activist scholarship. It thus remains of key importance to further explore visions of sustainability that do not only commit to meet technical requirements in human-led intervention upon the environment, but whose objective is to sustain other 'life projects' (Escobar, 1995), that might respond to different world-visions and epistemologies (Santos, 2014) and use different valuation languages and indicators (Martinez-Alier et al., 2010). Sustainability studies are urged therefore to inquiry more in depth into how violence, repression and criminalization of dissent operate as deliberate tools to delegitimize different views and to impede transformations to and protection of sustainabilities. 


\section{Conclusion}

Despite well-known controversial social and environmental impacts of dams, efforts to increase renewable energy generation have reinstated the interest into hydropower development globally. People affected by dams have largely denounced such 'unsustainabilities', yet in doing so, they are faced with violence and repression that usually remains invisible in impact assessments and less addressed in academic studies. We find that the resistance normally takes non-violence action and is not only defensive but also propositive. Despite that, repression, criminalization, violent targeting of activists and assassinations are recurrent features of conflictive dams. Violent repression is particularly high when indigenous people are involved. Indirect forms of violence are also analyzed through socio-economic, environmental, and health impacts. Worrying questions arise whether, where and how, the renewed interest into hydropower replicates patterns of violence in the frame of an 'extractivism of renewables'. Second, we suggest that violence targets not only opposition, but also curbs down the emergence of alternative visions and a pluralist worldview, what is also termed 'extractivist violence'. Third, we argue that co-production of knowledge should be largely encouraged in order to investigate sensitive topics in sustainability studies.

\section{Acknowledgements}

This research has been supported by the ENVJUSTICE project, funded by the European Research Council (ERC - grant agreement No 695446). The first and third authors also acknowledge the support of the ACKnowl-EJ project, with the support of the Transformations to Sustainability Programme, coordinated by the International Social Science Council-ISSC (Grant Number ISSC2015-TKN150317115354). We would like to thank all collaborators of the EJAtlas for their meticulous work and dedication in documenting the cases discussed here, as well as for their daily commitment for protecting and sustaining life. The constructive comments of three anonymous reviewers are acknowledged as well as from members of the ENVJUSTICE research team.

\section{Bibliography}

Acosta, A. 2013. El Buen Vivir: Sumak Kawsay, una oportunidad para imaginar otros mundos. Barcelona: Icaria.

Aditjondro, G., Kowalewski, D., 1994. Damning the Dams in Indonesia: A Test of Competing Perspectives. Asian Surv. 34.

Ahlers, R., Budds, J., Joshi, D., Merme, V., Zwarteveen, M., 2015. Framing hydropower as green energy: assessing drivers, risks and tensions in the Eastern Himalayas. Earth Syst. Dyn. 6, 195-204.

Amnesty International Annual Report 2016/2017. India. Available at: https://www.amnesty.org/en/countries/asia-and-the-pacific/india/report-india/

Andreucci, D., Kallis, G., 2017. Governmentality, Development and the Violence of Natural Resource Extraction in Peru. Ecol. Econ. 134, 95-103. 
Baviskar, A., 1995. In the belly of the river : tribal conflicts over development in the Narmada Valley, Studies in social ecology and environmental history. Oxford University Press.

Becker, H.A., Vanclay, F., 2003. The International Handbook of Social Impact Assessment. Edward Elgar Publishing, Inc.

Bell, D. M., \& Pahl, K. (2018). Co-production: towards a utopian approach. International Journal of Social Research Methodology, 21(1), 105-117.

Bosshard, P., 2009. China dams the world. World Policy Journal, 26(4), pp.43-51.

Bremer, S., \& Meisch, S., 2017. Co- production in climate change research: reviewing different perspectives. Wiley Interdisciplinary Reviews: Climate Change, 8(6).

Brown, P., 1997. Popular Epidemiology Revisited. Curr. Sociol. 45, 137-156.

Brismar, A., 2004. Attention to impact pathways in EISs of large dam projects. Environ. Impact Assess. Rev. 24, 59-87.

Buechler, S., Sen, D., Khandekar, N., Scott, C., 2016. Re-Linking Governance of Energy with Livelihoods and Irrigation in Uttarakhand, India. Water 8, 437.

Burma Rivers Network 2011. Statement of the Burma Rivers Network on the International Day of Action for Rivers. Available at:

http://burmariversnetwork.org/index.php?option=com_content\&view=article\&id=529:st op-damming-burmas-rivers\&catid=23\&Itemid=108. Last accessed 05 Jul 2017

Ceceña, A.E. 2009 Caminos y agentes del saqueo en América Latina. In alainet.org/active/33914.

Censat Agua Viva and Mining Watch Colombia 2009. Tierras y conflicto - Extracción de recursos, derechos humanos y la responsabilidad empresarial: compañías canadienses en Colombia

Cernea, M., 1997. The risks and reconstruction model for resettling displaced populations. World Dev. 25, 1569-1587.

Centro de Estudio para la Democracia 2016. Río Blanco: la reconstrucción histórica de la lucha por la defensa del Río Gualcarque. Available at: https://copinh.org/media/documents/2016/10/rio-blanco-final-con-portada_0.pdf

Cole, M.A., Elliott, R.J.R., Strobl, E., 2014. Climate Change, Hydro-Dependency, and the African Dam Boom. World Dev. 60, 84-98.

Conde, M., 2014. Activism mobilizing science. Ecol. Econ. 2014, 105:67-77

Conselho de Defesa dos Direitos da Pessoa Humana (CDDPH), 2010. Comissão Especial “Atingidos por Barragens" Resoluções no s 26/06, 31/06, 01/07, 02/07, 05/07. Available at: http://www.mabnacional.org.br/content/relat-rio-da-comiss-especial-doconselho-defesa-dos-direitos-da-pessoa-humana-2010. Last accessed: 23.02.17

Declaration of Temaca 2010. Available at: http://www.gritomesoamerica.org/index.php/component/content/article/127declaracion-encuentro-mundial-de-afectados-por-represas.html

Declaration of Curitiba, Affirming the Right to Life and Livelihood of People Affected 
by Dams 1997. Available at: https://www.internationalrivers.org/resources/the-curitibadeclaration-3678

Demaria, F., Schneider, F., Sekulova, F., Martinez-Alier, J., 2013. What is Degrowth? From an Activist Slogan to a Social Movement. Environ. Values 22, 191-215.

Dwivedi, R., 2002. Models and Methods in Development-Induced Displacement. Dev. Change 33, 709-732.

Erlewein, A., 2013. Disappearing rivers - The limits of environmental assessment for hydropower in India. Environ. Impact Assess. Rev. 43, 135-143.

Erlewein, A., Nüsser, M., 2011. Offsetting Greenhouse Gas Emissions in the Himalaya? Clean Development Dams in Himachal Pradesh, India. Mt. Res. Dev.

Escobar, A., 1995. Encountering development: the making and unmaking of the third world. Princeton University Press.

Escobar, A., 2004. Development, violence and the new imperial order. Development, 47(1), 15-21.

Escobar, A., 2008. Territories of difference: place, movements, life, redes. Duke University Press.

Escobar, A. 2014. Sentipensar con la tierra. Nuevas lecturas sobre desarrollo, territorio y diferencia. Colombia. Ediciones UNAULA (Colección Pensamiento vivo).

Escobar, A. 2017. Sustaining the Pluriverse: The Political Ontology of Territorial Struggles in Latin America. In The Anthropology of Sustainability (pp. 237-256). Palgrave Macmillan, New York.

Fals-Borda, O., 1987. The Application of Participatory Action-Research in Latin America. Int. Sociol. 2, 329-347.

Farmer, P., 1996. On Suffering and Structural Violence : A View from Below. Daedalus $125,261-283$.

Fearnside, P.M., 1999. Social Impacts of Brazil's Tucuruí Dam. Environ. Manage. 24, 483-495.

Fearnside, P.M., 2004. Greenhouse Gas Emissions from Hydroelectric Dams: Controversies Provide a Springboard for Rethinking a Supposedly "Clean” Energy Source. An Editorial Comment. Clim. Change 66, 1-8.

Fearnside, P.M., 2015. Brazil’s São Luiz do Tapajós Dam: The Art of Cosmetic Environmental Impact Assessments 8, 373-396.

Fearnside, P.M., 2016. Environmental and Social Impacts of Hydroelectric Dams in Brazilian Amazonia: Implications for the Aluminum Industry. World Dev. 77, 48-65.

Fearnside, P.M., Pueyo, S., 2012. Greenhouse-gas emissions from tropical dams. Nat. Clim. Chang. 2, 382-384.

Franco, J., Feodoroff, T., Kay, S., Santos, R., 2014. The Global Water Grab A primer. Transnational Institute

Frontline Defenders (2016) Environmental Rights Defenders at Risk in Peru. Available at: https://www.frontlinedefenders.org/en/statement-report/environmental-rights- 
defenders-risk-peru. Last accessed 03.03.17

Galtung, J., 1969. Violence, Peace, and peace Research. J. Peace Res. 6, 167-191

Global Witness, 2017. Honduras: el país más peligroso del mundo para el Activismo Ambiental. Available at: https://www.globalwitness.org/en/campaigns/environmentalactivists/honduras-el-pa\%C3\%ADs-m\%C3\%A1s-peligroso-del-mundo-para-elactivismo-ambiental/. Last accessed: $05 \mathrm{Jul} 2017$

Global Witness 2016. On dangerous grounds. Available at:

https://www.globalwitness.org/en/campaigns/environmental-activists/dangerousground/. Last accessed: 05 Jul 2017

Global Witness 2015. How Many More? Available at:

https://www.globalwitness.org/en/campaigns/environmental-activists/how-many-more/. Last accessed: 05 Jul 2017

Goldman, M., 2001. Constructing an Environmental State: Eco-governmentality and other Transnational Practices of a "Green" World Bank. Soc. Probl. 48, 499-523.

Goldsmith, E., Hildyard, N., 1984. The social and environmental effects of large dams. Sierra Club Books.

Gregory, D., Pred, A., 2007. Violent geographies: fear, terror, and political violence. Routledge.

Grosfoguel, R. 2016. Del «extractivismo económico» al «extractivismo epistémico»y «extractivismo ontológico»: una forma destructiva de conocer, ser y estar en el mundo. Tabula Rasa, 24.

Grumbine, R.E., Pandit, M.K., 2013. Ecology. Threats from India's Himalaya dams. Science 339, 36-7.

Gudynas, E. 2016. Teología de los extractivismos. Tabula Rasa 24.

Haya, B., Payal, P., 2011. Hydropower in the CDM : Examining Additionality and Criteria for Sustainability.

Hildyard, N., et al., 2012. Energy Security For Whom? For What? The Corner House

Holterman, D., 2014. Slow violence, extraction and human rights defence in Tanzania: Notes from the field. Resour. Policy 40, 59-65.

Huber, A., Joshi, D., 2015. Hydropower, Anti-Politics, and the Opening of New Political Spaces in the Eastern Himalayas. World Dev. 76, 13-25

International Hydropower Association 2017. Hydropower Status Report. Available at: https://www.hydropower.org/2017-hydropower-status-report. Last Accessed 05 Jul 2017

International Rivers 2012. The new great walls: a guide to China's overseas dam industry.

Jasanoff, S., 2004. States of Knowledge: The Co-Production of Science and Social Order. Routledge

Kirchherr, J., Charles, K.J., 2016. The social impacts of dams: A new framework for scholarly analysis. Environ. Impact Assess. Rev. 60, 99-114. 
Kuenzer, C., Campbell, I., Roch, M., Leinenkugel, P., Tuan, V.Q., Dech, S., 2013. Understanding the impact of hydropower developments in the context of upstreamdownstream relations in the Mekong river basin. Sustain. Sci. 8, 565-584.

Le Billon, P., 2014. Wars of Plunder Conflicts, Profits and the Politics of Resources. Columbia University Press.

Martínez-Alier, J., 2002. The environmentalism of the poor: a study of ecological conflicts and valuation. Cheltenham: Edward Elgar.

Martínez-Alier, J., Kallis, G., Walter, M., Temper, L., Veuthey, S., 2010. Social Metabolism, Ecological Distribution Conflicts, and Valuation Languages. Ecol. Econ.

Martínez-Alier, J., Temper, L., Del Bene, D., Scheidel, A., 2016. Is there a global environmental justice movement? J. Peasant Stud. 43, 731-755.

McCully, P., 1996. Silenced rivers: the ecology and politics of large dams. ZED Books

McCully, P., 2000. The use of a trilateral network: An activist's perspective on the Formation of the World Commission on Dams. Am. U. Int'l L. Rev., 16, 1453.

McDonald, K., Bosshard, P. and Brewer, N., 2009. Exporting dams: China's hydropower industry goes global. Journal of environmental management, 90, pp.S294S302.

Middleton, C., 2012. Transborder Environmental Justice in Regional Energy Trade in Mainland South-East Asia. Austrian J. South-East Asian Stud. 5, 292-315.

Milanez, F., 2015. Memórias sertanistas: cem anos de indigenismo no Brasil. Edições Sesc São Paulo

Mingorría, S., 2016. Violencia, silencio, miedo: El desvelo del conflicto de palma aceitera y caña de azúcar en el valle del Polochic, Guatemala. Ecol. política, ISSN 1130-6378, No 51, 2016, págs. 73-78 73-78.

Moore, J. W. 2000. Sugar and the expansion of the early modern world-economy: Commodity frontiers, ecological transformation, and industrialization. Review (Fernand Braudel Center), 409-433.

Navas, G., Mingorría, S., \& Aguilar-González, B. 2018. Violence and resistance: An analysis of 95 Environmental conflicts in Central America. Sustain Sci.

Nixon, R., 2011. Slow violence and the environmentalism of the poor. Harvard University Press.

Office of the United Nations High Commissioner for Human Rights (OHCHR), 2016. Environmental Human Rights Defenders, Report of the Special Rapporteur on the situation of human rights defenders (Last accessed 05.07.17)

Peluso, N.L., Watts, M., 2001. Violent environments. Cornell University Press.

Plummer Braeckman, J., Guthrie, P., 2016. Loss of value: effects of delay on hydropower stakeholders. Proc. Inst. Civ. Eng. - Eng. Sustain. 169, 253-264.

Pottinger, L., 2008. "Bad Deal for the Planet: Why Carbon Offsets Aren't Working And How to Create a Fair Global Climate Accord," Dams, Rivers and People Report. 
International Rivers, Berkeley, CA.

Rodgers, D., O’Neill, B., 2012. Infrastructural violence: Introduction to the special issue. Ethnography 13, 401-412.

Rosenberg, D.M., McCully, P., Pringle, C.M., 2000. Global-Scale Environmental Effects of Hydrological Alterations: Introduction. Bioscience 50, 746.

Santos, B. de S., 2014. Epistemologies of the South: justice against epistemicide. Paradigm Publishers

Scheidel, A. and Sorman, A.H., 2012. Energy transitions and the global land rush: Ultimate drivers and persistent consequences. Global Environmental Change, 22(3), 588-595.

Scheidel, A., Temper, L., Demaria, F., Martinez-Alier, J. (this feature). Ecological distribution conflicts as forces for sustainability: an overview and conceptual framework. Sustainability Science, this feature. DOI: 10.1007/s11625-017-0519-0.

Schlosberg, D., 2004. Reconceiving Environmental Justice: Global Movements And Political Theories. Environmental Poliics, 13, 517-540.

Scott JC., 1998. Seeing Like a State: How Certain Schemes to Improve the Human Condition Have Failed. New Haven, CT: Yale University Press.

Siciliano, G., Urban, F., Tan-Mullins, M., Pichdara, L., Kim, S., 2016. The Political Ecology of Chinese Large Dams in Cambodia: Implications, Challenges and Lessons Learnt from the Kamchay Dam. Water 8, 405.

Sikor, T., \& Newell, P., 2014. Globalizing environmental justice?. Geoforum, 54, 151157.

Sovacool, B.K., Bulan, L.C., 2013. They'll be dammed: the sustainability implications of the Sarawak Corridor of Renewable Energy (SCORE) in Malaysia. Sustain. Sci. 8, 121-133.

Springer, S., 2012. Neoliberalising violence: of the exceptional and the exemplary in coalescing moments. Area 44, 136-143.

Springer, S., Le Billon, P., 2016. Violence and space: An introduction to the geographies of violence. Polit. Geogr. 52, 1-3.

Shrivastava, A., Kothari, A., 2012. Churning the Earth: The Making of Global India. Penguin Books Limited.

Syvitski, J.P.M., 2008. Deltas at risk. Sustain. Sci. 3, 23-32.

Survival International, 2010. Severe Damage report. Available at: http://assets.survivalinternational.org/documents/373/Serious_Damage_final.pdf. Accessed on 20.02.2018

Temper, L., Del Bene, D., Martinez-Alier, J., 2015. Mapping the frontiers and front lines of global environmental justice : the EJAtlas. J. Polit. Ecol. 22, 256.

Temper L., Del Bene D., 2016. Transforming knowledge creation for environmental and epistemic justice. Curr. Opin. Environ. Sustain. 20:41-49.

Temper, L., Walter, M., Rodriguez, I., Kothari, A., \& Turhan, E. (2018). A perspective 
on radical transformations to sustainability: resistances, movements and alternatives. Sustainability Science, 1-18.

Teran-Mantovani, E. (2017). Inside and beyond the Petro-State frontiers: geography of environmental conflicts in Venezuela's Bolivarian Revolution. Sustainability Science, $1-15$.

Urban, F., 2014. Large Dams in Asia : Contested Environments between Technological Hydroscapes and Social Resistance 34, 307-308.

Urban, F., Nordensvard, J., Siciliano, G., Li, B., 2015. Chinese Overseas Hydropower Dams and Social Sustainability: The Bui Dam in Ghana and the Kamchay Dam in Cambodia. Asia Pacific Policy Stud. 2, 573-589.

World Commission on Dams 2000. Dams and Development. A new Framework for Decision-Making. Earthscan Publications Ltd

Xarxa per la Sobirania Energetica, 2018. Tenim l'Energia. Icaria, Barcelona.

Yacoub, C. (2015). Agua y Ecología Política: El extractivismo en la agroexportación, la minería y las hidroeléctricas en Latinoamérica. B. Duarte, \& R. Boelens (Eds.). Quito: Abya-Yala.

Zarfl, C., Lumsdon, A.E., Berlekamp, J., Tydecks, L., Tockner, K., 2014. A global boom in hydropower dam construction. Aquat. Sci. 77, 161-170.

\section{References to EJAtlas cases}

EjAtlas (2014) Sivens Dam on Tescou river, France. In: Atlas of Environmental Justice. http://ejatlas.org/conflict/testet-dam-france. Accessed 24 Feb 2017

EJAtlas (2015a) Kariba Dam, Zambia/Zimbabwe. In: Atlas of Environmental Justice. http://ejatlas.org/conflict/kariba-dam-zambia-zimbabwe. Accessed 24 Feb 2017

EJAtlas (2015b) Chixoy Dam and Rio Negro massacre, Guatemala. In: Atlas of Environmental Justice. http://ejatlas.org/conflict/chixoy-dam-guatemala. Accessed 24 Feb 2017

EJAtlas (2015c) Yacyreta Dam on the Parana River, Argentina-Paraguay. In: Atlas of Environmental Justice. http://ejatlas.org/conflict/yacyreta-dam-on-the-parana-riverargentina. Accessed 06 Apr 2017.

EJAtlas (2016a) Proyecto Hidroeléctrico Agua Zarca, Honduras. In: Atlas of Environmental Justice. http://ejatlas.org/conflict/proyecto-hidroelectrico-agua-zarcahonduras. Accessed 24 Feb 2017

EJAtlas (2016b) Urra Dam on the Sinu River, Colombia In: Atlas of Environmental Justice. http://ejatlas.org/conflict/urra-dam-on-the-sinu-river-colombia. Accessed 27 Nov 2017

EJAtlas (2016c) Akosombo Dam, Ghana. In: Atlas of Environmental Justice. http://ejatlas.org/conflict/akosombo-hydroelectric-project-ghana. Accessed 24 Feb 2017 
EJAtlas (2016d) Sardar Sarovar, India. In: Atlas of Environmental Justice. http://ejatlas.org/conflict/sardar-sarovar-dam-india. Accessed 24 Feb 2017

EJAtlas (2016e) Maheshwar Dam, India. In: Atlas of Environmental Justice. http://ejatlas.org/conflict/maheshwar-dam-narmada-valley-india. Accessed 24 Feb 2017

EJAtlas (2016f) Ralco HEP and Bio Bio Watershed hydro plans, Chile. In: Atlas of Environmental Justice. http://ejatlas.org/conflict/bio-bio-watershed-targeted-byministry-of-energys-hydro-plans-chile. Accessed 27 Feb 2017

EJAtlas (2016g) Hidroeléctrica El Naranjal, Veracruz, Mexico. In Atlas of Environmental Justice. http://ejatlas.org/conflict/el-naranjal-veracruz-mexico. Accessed 28 Feb 2017

EJAtlas (2016h) Hidro Santa Rita, Guatemala. In Atlas of Environmental Justice. http://ejatlas.org/conflict/hidro-santa-rita-monte-olivo-guatemala. Accessed 19 May 2017

EJAtlas (2017a) El Quimbo hydroelectric project, Colombia. In Atlas of Environmental Justice http://ejatlas.org/conflict/el-quimbo-hydroelectric-project-colombia. Accessed 24 Feb 2017

EJAtlas (2017b) Angostura hydropower project, Chile. In: Atlas of Environmental Justice. http://ejatlas.org/conflict/angostura-dam-chile. Accessed 05 Jul 2017

EJAtlas (2017c) Hidroelectricas y violencia en San Mateo Ixtatán, Guatemala. In: Atlas of Environmental Justice. http://ejatlas.org/conflict/san-mateo-ixtatan. Accessed 27 Nov 2017

EJAtlas (2017i) Proyecto hidroeléctrico Corpus Christi, Argentina-Paraguay. In Atlas of Environmental Justice. http://ejatlas.org/conflict/proyecto-hidroelectrico-corpus-christi. Accessed 27 Nov 2017 